The $5^{\text {th }}$ International Conference on Family Business and Entrepreneurship

\title{
THE STUDY OF TOKOPEDIA RE-PURCHASE INTENTION DURING COVID-19 PANDEMIC
}

\author{
Putri Permata Sari ${ }^{1 *}$, Filda Rahmiati ${ }^{2}$ \\ ${ }^{1}$ Faculty of Business, President University \\ ${ }^{2}$ Faculty of Business, President University \\ Corresponding author: putriprmta25th@gmail.com
}

\begin{abstract}
:
This study aims to determine the impulsive behaviour using a brand image, brand ambassadors, service quality, and customer satisfaction on Tokopedia re-purchase intention. In this study, a quantitative approach was used to collect data from an online questionnaire (Google Form) for the Tokopedia users who had made a transaction more than once. The online questionnaire was distributed via social media and received 145 valid responses, with PLS-SEM being used to analyze the hypothesis testing of this research. The result shows that brand image indirectly influences the re-purchase intention of Tokopedia mediated by impulsive behaviour. The brand ambassador also has an indirect influence on the re-purchase intention of Tokopedia mediated by customer satisfaction and impulsive behaviour, and service quality has a direct and indirect influence on the re-purchase intention of Tokopedia mediated by customer satisfaction. Furthermore, customer satisfaction and impulsive behaviour have a significant influence on the re-purchase intention of Tokopedia. Tokopedia must pay attention to factors interested in re-purchase intention, which means that Tokopedia should maintain service quality and customer satisfaction and improve customers' experience when customers make impulsive behaviour.
\end{abstract}

Keywords: Brand Image, Brand Ambassador, Impulsive Buying, Repurchase Intention, Satisfaction, Service Quality.

\section{Introduction}

The development of internet technology is happening very rapidly in the business world, especially in Indonesia. Electronic Commerce (E-commerce) has made internet competence as a medium for transactions that are fast and easy to access (Gita \& Setyorini, 2016). E-commerce has dramatically increased. As of January 2020, the number of internet users in Indonesia has reached 175,4 million people, or around 64\% of the total population in Indonesia (Hootsuite, 2020). Added, Indonesia's E-commerce revenue in 2019 reached \$20,4 million (STATISTA, 2020). Especially during the COVID-19 Pandemic, it causes a positive response of people who switch to do transactions through e-commerce, also consumers as direct partners in a business transaction changes (Santoso, 2020). In addition, the COVID-19 Pandemic has changed the behaviour of both consumers and producers, which forces individuals to carry out physical distancing as an effort made by the government on preventing the COVID-19 outbreak. Partner of East Ventures, Melisa Irene, stated that the restrictions on activities outside the home encourage Indonesians to shop online more frequently. Apart from that, trying different apps to work remotely and consume more digital content (Setyowati, 2020).

Driven by a tight map of technology business competition in Indonesia, many marketplaces and ecommerce businesses have emerged with various features and offerings. Tokopedia is a local e-commerce company that operates in Indonesia. It has the most significant monthly active users in Southeast Asia (Devita et al., 2020). It makes one of them has most significant digital-based buying and selling companies 
in Indonesia (Gideon, 2018). According to its mission to achieve digital economic equality, Tokopedia provides a market business model and online mall that allows individuals, small shops, and brands to open and manage their online stores. Tokopedia created $10.3 \%$ of the total employment in Indonesia and helped increase sales by $22 \%$ in various cities and provinces in Indonesia nationally (TOKOPEDIA, 2020).

Brand image plays a significant role to make consumers interested in the product. The brand image leads to an interest of customers in consuming or knowing more about a product's information (Cahyowulan, 2018). The image can be built through good communication from a company, starting from using characteristics that are not easily changed or consistent because something remains easy to remember (Gita, 2016). At the end of June 2020, Tokopedia provides shopping solutions by launching a program named "Waktu Indonesia Belanja", or WIB. Here are various offers that will be obtained in the WIB program each month. Tokopedia WIB TV show program presents special appearances from several top Indonesian artists, such as Rich Brian, Noah, Raisa, Project Pop, and outside the country, especially K-Pop stars to fill in the WIB program. So far, WIB has successfully invited several K-Pop artists, including BTS, TWICE, Secret Number, ITZY, DAY6, and Blackpink. According to Bagus (2020), Tokopedia presents various digital innovations in WIB, one of which is the 'Select Your Artists' feature. Through this feature, people can choose their favourite artist, from the 25th to the end of each month, to appear on the next Tokopedia WIB TV Show.

Tokopedia carries the K-Pop group BTS in 2019 as their brand ambassador and continues in 2021 with BTS and BLACKPINK as their new brand ambassador. Brand ambassadors or celebrity endorsement will help create a solid emotional connection between a brand or a company and indirectly build the image of the product's impact on purchasing decisions and product usage (Wang \& Hariandja, 2016). Utilizing a celebrity as an endorser is indeed easier to affect the psychological consumption of consumers. It will create a positive perception of the product it promotes and increases purchase intention (Haryantana \& Ekawati, 2015). Hallyu is a phenomenon of the rapid growth of Korean culture through the media mass (Febrina, 2017). In October 2019, BTS was officially becoming Tokopedia's brand ambassador because it has a journey and vision in line with the company to portray Tokopedia's brand to spread a positive message throughout the world (TOKOPEDIA, 2020).

On the other hand, quality of service in the context of E-commerce is increasingly recognized as an effective way to gain and maintain a competitive advantage. Aryani dan Rosnita (2010) stated that service quality encourages customers to commit to a company's products and services to increase the market share of a product. Zakaria and Suwitho (2019) mentioned that the quality of service provided to consumers could influence satisfaction to customers. These results indicate that the better the quality of service, the more customer satisfaction increases. Tokopedia facilitates good service quality for its customers by providing recommendations for shops that have a good reputation or verified sellers (power merchants) also provides customer service to streamline the process of returning money or guarantees if there are problematic items to create shopping security where this quality of service cannot be obtained if customers buy on a platform or individual seller. More than that, in April 2021, Tokopedia has just launched a new health insurance product called Covid-19 Protection to make it easier for the customers to get more protection from the risks of COVID-19 and accidents at very affordable costs (Damar, 2021).

E-commerce has become a habit for some people because of the convenience provided. Many people assume that online shopping in E-commerce is one of the means to find the items they need may be the cause of the customer's impulsive behaviour. According to Utami \& Siskaliswati (2013), impulsive behaviour occurs when consumers experience a solid and persistent desire to buy something as soon as possible. Supported by the condition, searching information for desired needs, the COVID-19 Pandemic has reduced the need for shopping directly to shops or retails and replaced them with online purchases (Utari et al., 2020).

Re-purchase intention will emerge after consumers think about the experiences they have experienced before (Burhanuddin, 2018). Additionally, a study from Aparcio et al. (2021) states that an extension to the technology acceptance model (TAM2) provides a detailed insight into how both the social influence and the instrumental cognitive processes influence the intentions of use and focuses on the main determinants of re-purchase as a way of achieving customer retention.

Tokopedia is the most substantial monthly active user. However, even though the data showed on Quarterly Data on the Number of Visitors of Tokopedia during the 2nd and 4th quarter of 2020 was increasing, the data from 2nd quarter to 3 rd quarter of 2019 was decreased significantly until the 1 st quarter of 2020. This is because the company found the existence of data theft of users nearly 15 million of customer data. Although, if a problem like this often occurs on several e-commerce platforms, especially Tokopedia, this will impact the brand image of Tokopedia users of the services that Tokopedia has been built. 
Based on the above explanation, this research will be analyzing customers of Tokopedia during the COVID19 Pandemic. This study is expected to prove that the people who transaction on Tokopedia during the COVID-19 Pandemic since all the activities should be done at home is interested in impulse buying based on the brand image, brand ambassador, the service quality, and based on the experience of online shopping at Tokopedia re-purchase intention to shopping again at Tokopedia even in this COVID-19 pandemic situation.

\section{Literature Review}

Re-purchase Intention

Re-purchase intention is a purchase interest based on the purchase experience that has been made in the past (Thamrin \& Francis, 2012). The high re-purchase intention reflects a high level of satisfaction from consumers when deciding to buy a product. Re-purchase intention is one component of subconscious customer behaviour about how someone intends to repeat order certain goods. According to Salisbury et al. (2001), re-purchase intention in an online shopping environment will determine the strength of the customer's intention to make a certain purchase via the internet. Laroche et al. (2010) emphasized that variables such as consideration in buying a brand and the expectation to buy a brand can be used to measure customer re-purchase intentions. Ferdinand (2002) states that the indicators of re-purchase intention include:

1. Transactional Interests.

2. Referential Interests.

3. Preferential Interests.

4. Exploratory Interests.

\section{Customer Satisfaction}

The key to the success of a company in an industry with a high level of competition and environmental change lies in how far the company can satisfy the needs and wants of its target market. According to Kotler, Philip, \& Keller (2009) cited the more benefits or increasing the product offered to customers, the higher the value the customer thinks. This means encouraging customers to make re-purchase intention will be even higher. Customer satisfaction is a customer evaluation of a product or service in terms of whether the product and service have met the needs and expectations of the customer (Bitner \& Zeithaml, 2003); satisfying the wants and needs of customers has a positive impact on the company. In addition, Komalig and Rondonuwu (2013) and Komalig (2013) customer satisfaction is measured by how well the expectations of consumers or customers are met. The consumer satisfaction indicators comprise of:

1. Fulfilment of consumer expectations

2. Attitude or desire to use the product

3. Recommend to others

4. Service Quality

5. Good Reputation

\section{Impulsive Behavior}

Hirschman et al. (2009) define impulsive buying behaviour as the tendency of consumers to make purchases spontaneously, are not reflected, rushed and driven by emotional, psychological aspects of a product, and are tempted by the persuasion of marketers. Impulsive buying behaviour is a condition that occurs when an individual experiences a sudden feeling of urgency that cannot be resisted (Solomon \& Rabolt, 2009). This propensity to buy spontaneously can generally result in a purchase when the consumer believes it is natural. In addition, Septila and Aprilia (2017) stated that impulsive buying behavior is buying behavior that is done to meet needs and fulfil desires and self-concept and lifestyle demands. The cause of the emergence of such conditions is the environmental stimulus that generates and optimizes the function of the desire.

According to Loudon and Bitta (2004) revealed that the aspects that impact impulsive buying behaviour include: Products with the characteristics of low prices, small or marginal needs, short-term products, trim sizes, and easily accessible stores, Marketing and marketing, which includes distribution in a large number of self-service outlets, highly suggestible and continuous advertising through mass media, point-of-sale advertisements, display positions, and prominent store locations, and Consumer characteristics such as personality, gender, socio-demographic or socioeconomic characteristics. A study by Anh and Kwon (2020) stated that impulsive buying behaviour is considered a widespread phenomenon and influences other behaviors like the chronic impulse customers tend to experience increased urges to buy in the cruise context. 
The tendency might be accompanied by stronger desire than emotions. Loudon and Bitta (2004) provide indicators for impulsive behaviour includes:

1. Spontaneity

2. Strength, compulsion, and intensity

3. Excitement and stimulation

4. Disregard of consequences

\section{Brand Image}

The brand image allows consumers to get to know a product, evaluate the quality, and cause risks of low purchase. Consumers generally prefer a brand famous even though sometimes the price offered is more expensive. The importance of developing a brand image in a re-purchase decision is because a wellmanaged brand image will produce positive consequences, such as increasing consumer confidence in a product and can improve understanding of aspects of customer behaviour in making purchasing decisions (Wicaksono, 2007). Aaker (2003) cited that the better the brand image for consumers, the greater the repurchasing decisions on products. Kotler and Keller (2016) added that brand image is the consumer's perception of a brand as a reflection of the associations that exist in the minds of consumers.

Kotler \& Keller (2016) and Aaker (2010) describe the indicators of brand image as follows:

1. Recognition

2. Reputation

3. Brand Identity

4. Brand Personality

5. Brand Association

6. Brand Attitude and Behavior

\section{Brand Ambassador}

Lea-Greenwood (2012) describes a brand ambassador as a tool companies use to communicate and connect with the public regarding how they enhance sales. The company carries out the use of brand ambassadors to influence or invite consumers. It aims to make consumers interested in using the product, primarily because brand ambassador selection is usually based on imaging through a celebrity (Royan, 2004). One of the primary and most noticeable differences in seeing the product is a celebrity (the endorser) who supports it. The concept of celebrity endorser shall be harmonized and in accordance incongruity (Nugraha, Kusumawardani, \& Octavianie, 2018). Before the product reaches global recognition, the products are relatively inexpensive on the equation stage of the cycle. Lea-Greenwood (2012) also added that brand ambassadors are instrumental in helping the smooth running of marketing activities both locally and globally. Lea-Greenwood (2012) provides indicators of brand ambassador can be measured as follows. However, this study is concerned with four indicators such as:

1. Congruence

2. Credibility

3. Attractiveness

4. Power

\section{Service Quality}

Quality is a condition that is very influential with products, services, people, processes, and the environment that meet or exceed hope (Tjiptono, 2016). Service quality is a necessity that companies must do to survive and still get customer trust and satisfaction. Service quality also provides a strategic advantage for companies as competitors will find it difficult to imitate their service quality standards. Tjiptono (2016) also cited that service quality can be identified by comparing consumers' perceptions of the service they receive or receive with the service they expect or want for the service attributes of a company. According to Setyobudi and Bintoro (2014), in general, service is an activity or a series of invisible activities that cannot be felt that occur as a result of interactions between consumers and employees or other things provided by service providers that are intended to solve consumer problems. According to Yulianto (2017), service quality indicators are as follows:

1. Skills and professionalism.

2. Flexibility and convenience

3. Trustworthiness and reliability

4. Service coverage 
5. Credibility and Reputation

Hypotheses Development

The relationship between Brand Image towards the Re-purchase Intention on Tokopedia

A study found that the brand image of the company or a platform can give a sense of satisfaction so that consumers are willing to re-purchase the same product later. Influence customer satisfaction (Setiawan, 2018; Yana, 2015). In addition, the brand image itself is related to the reputation and credibility of the brand, which will lead to impulsive behaviour that is carried out without having the intention or intention to buy beforehand (Zikra, 2020).

Tanady and Fuad (2020) also Dewi and Ekawati (2019) explained that the brand image has been built and owned by a brand that consumers will perceive will be able to encourage the higher desire of consumers to make a transaction and have an intention to re-purchase the product or goods on that platform. Furthermore, Syahrivar et al. (2020) stated that a brand with a positive image in the minds of consumers would have a greater chance of being re-purchased in the future than a brand with a lower image. Based on these statements, a research hypothesis can be proposed as:

H1: There is an influence of Brand Image on Customer Satisfaction on Tokopedia.

$\mathrm{H} 2$ : There is an influence of Brand Image on the Impulsive Behavior of Tokopedia.

H3: There is an influence of Brand Image on the Re-purchase Intention on Tokopedia.

H4: There is an influence of Brand Image towards the Re-purchase Intention on Tokopedia mediated by Customer Satisfaction

H5: There is an influence of Brand Image towards the Re-purchase Intention on Tokopedia mediated by Impulsive Behavior.

\section{The relationship between Brand Ambassador towards the Re-purchase Intention on Tokopedia}

Brand ambassadors will help make a stronger emotional connection between a brand or company and build customer satisfaction. It will indirectly create a good image that impacts purchasing decisions and product use (Febrina \& Sampurno, 2017). Furthermore, Fitriana (2020) strengthens that satisfaction with a product or service is obtained after a customer sees an advertisement by a brand ambassador and raises interest in buying the product or service until an experience occurs. In addition, Rinaldi and Tanapli's (2020) study shows that products related to brand ambassadors of a platform are made to keep up with the times in society, resulting in unplanned purchases to meet the hedonic needs of their desire. Furthermore, Savitri (2017) and Sugianto (2014) found that Brand ambassadors positively influence purchase interest. Based on the results of these statements, a research hypothesis can be proposed as:

H6: There is an influence of Brand Ambassador towards the Customer Satisfaction on Tokopedia.

H7: There is an influence of Brand Ambassador towards the Impulsive Behavior on Tokopedia.

H8: There is an influence of Brand Ambassador towards the Re-purchase Intention on Tokopedia.

H9: There is an influence of Brand Ambassador towards the Re-purchase Intention on Tokopedia mediated by Customer Satisfaction.

H10: There is an influence of Brand Ambassador towards the Re-purchase Intention on Tokopedia mediated by Impulsive Behavior.

\section{The relationship between Service Quality towards the Re-purchase Intention on Tokopedia}

Carrying out the competition in the world of E-commerce platforms, each company in Indonesia strives to provide the best quality service to create customer satisfaction (Tanady \& Fuad, 2020) as consumers tend to evaluate or assess the quality of services offered to feel satisfied with the services, they receive. Furthermore, consumers who feel satisfied with the services provided by the company will do repeat orders or become loyal customers and have the intention to re-purchase on that platform. Good service quality is satisfying and following the service expected by the customer. The better the services provided, the faster the decisions made by consumers in deciding to do impulse buying (Ningsih, 2018). In addition, Hidayat (2016), service quality has a significant influence on impulsive behaviour and stated that good service quality covering all non-physical facilities offered by the company to customers is a factor in the emergence of impulsive behaviour. Based on the results of these statements, a research hypothesis can be proposed as: H11: There is an influence of Service Quality on Customer Satisfaction on Tokopedia.

H12: There is an influence of Service Quality towards Impulsive Behavior on Tokopedia.

H13: There is an influence of Service Quality towards the Re-purchase Intention on Tokopedia.

H14: There is an influence of Service Quality towards the Re-purchase Intention on Tokopedia mediated by Customer Satisfaction.

H15: There is an influence of Service Quality towards Repurchase Intention on Tokopedia mediated by 
Impulsive Behavior.

The relationship between Customer Satisfaction and the Re-purchase Intention on Tokopedia

Consumer satisfaction will be a significant cause behind the re-purchase of certain products on a platform (Kusumadewi \& Saraswati, 2020) found that customer satisfaction significantly influenced the re-purchase intention (Fildayanti, 2020). With the high sense of satisfaction that consumers feel given by a product, it will also have the potential to encourage consumer intention to repeat purchases of the product at a later date because it gets a positive impression with previous experiences (Dewi \& Ekawati, 2019). Based on the results of these statements, a research hypothesis can be proposed as:

H16: There is an influence of Customer Satisfaction towards the Re-purchase Intention on Tokopedia.

The relationship between Impulsive Behavior and the Re-purchase Intention on Tokopedia

Consumers' impulsive behaviour can be seen in modern society today since the customer only buys popular things without careful planning. If the turmoil has not been resolved, this will undoubtedly make consumers feel satisfied and calm (Parsad et al., 2017). Impulsive purchases in consumers and post-purchase behaviour towards re-purchase intention make consumers more confident to prefer using e-commerce as a shopping site in a sustainable manner (Maulana, 2020). Based on the results of these statements, a research hypothesis can be proposed as:

H17: There is an influence of Impulsive Behavior towards the Re-purchase Intention on Tokopedia

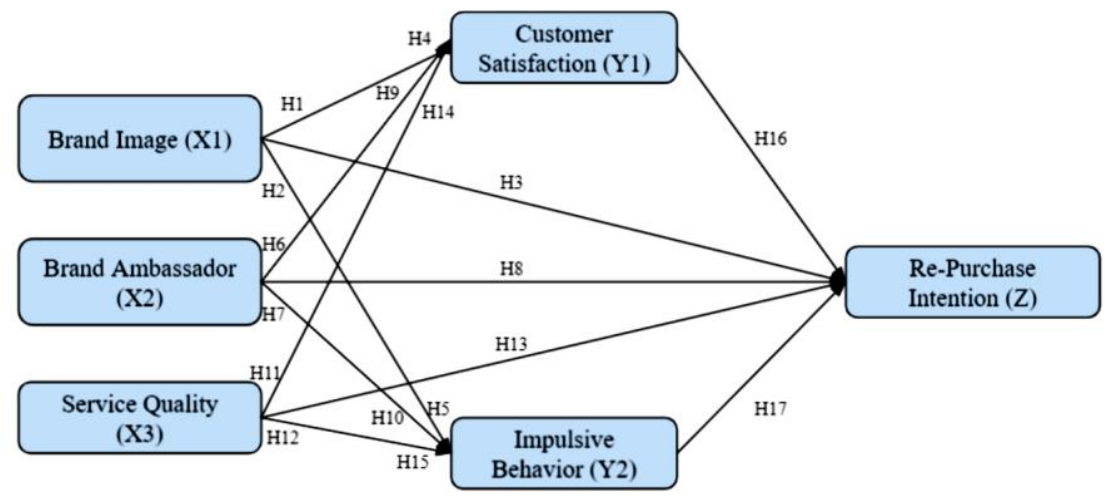

Figure 1. Research framework

\section{Research Method}

Sampling methods and data collection

In this study, a survey was conducted to obtain empirical data. The sample population was selected using a convenient sampling technique from people who had done online shopping at Tokopedia during the COVID-19 Pandemic. Out of 162 sets of questionnaires, three were excluded due to outliers, and 145 sets of questionnaires were for the final analysis. According to the demographic profile of the 110 respondents, the majority of respondents are female (60\%) at the age of $15-24$ years old $(67 \%)$. Moreover, over half of the respondents (51percent) are students, whereas $34 \%$ were private employees. Majority of respondents' monthly income were $<$ IDR 1,500,000 (37\%) and IDR 3,000,000-7,000,000 (34\%).

\section{Construct measurement}

The construct measurement in this study has been developed to evaluate variables in the model. One of the scales is Brand Image adapted from Aaker (2010) and Kotler and Keller (2016) with six items. Additionally, Lea-Greenwood (2012) provides four items used to measure the Brand Ambassador. Five items from Yulianto (2017) evaluate Service Quality. Customer Satisfaction measure using four items adapted from Komalig and Rondonuwu (year). Based on Loudon \& Bitta (2004), four items measure Impulsive Behavior. Last, four items from Ferdinand (2002) are used to evaluate their Re-purchase Intention.

\section{Data analysis}

In the current study, the Partial Least Square-based Structural Equation Modelling (PLS-SEM) was employed using the SmartPLS software, version 3.2.8. PLS-SEM is the most common implementation as 
a path model. PLS is the most suitable technique where the research objective is predictive or exploratory modelling (Garson, 2016). The PLS-based SEM contains two models: the measurement model and the structural model. In addition, this study uses a reflective model in which measurement covariates are influenced by latent constructs (Ghozali \& Latan, 2015; Hair et al., 2019).

Hair et al. (2019) were also used the influence of vector mediation on the hypothesis as the approach. The four steps to this approach are as follows: 1 . This study examines the independent variable's effect on the model's dependent variable by involving the mediating variable (effect A). 2. Check the independent variable's impact on the model's dependent variable without affecting the mediating variable (effect B). 3 . Examining the effect of the independent variable on the mediating variable in the model (effect $\mathrm{C}$ ), four and examining the effect of the mediating variable on the dependent variable in the model (effect D).

\section{Results and Discussion}

Measurement model test

The measurement model refers to the relationships between a latent construct and its indicators. The first criterion for assessing the reflective measurement model in the PLS-SEM is examining the reliability and the validity of measures (Hair et al., 2017). For the construct reliability, the measurement model results (Table I) reported that Cronbach's $\alpha$ values were above 0.60 , and composite reliability (CR) values were above 0.70, meaning the constructs were reliable (Hair et al., 2019). According to Hair (Fathi, 2014), the item loadings for convergent validity, more than 0.5, can be categorized as valid. AVE (Average Variance Extracted) statistics for each construct ranged between 0.727 and 0.852 , which were moderately higher than the suggested threshold of 0.5 (Hair et al., 2019), showing adequate convergent validity for all constructs.

Table 1. Measurement model assessment analysis

\begin{tabular}{lccc}
\hline Variable & AVE & $\alpha$ & CR \\
& & & \\
\hline Brand Image & 0.732 & 0.927 & 0.943 \\
Brand Ambassador & 0.745 & 0.914 & 0.936 \\
Service Quality & 0.727 & 0.906 & 0.930 \\
Customer Satisfaction & 0.809 & 0.921 & 0.944 \\
Impulsive Behavior & 0.852 & 0.942 & 0.958 \\
Repurchase Intention & & & \\
& 0.816 & 0.925 & 0.947 \\
\hline
\end{tabular}

The Fornell-larger criterion is recommended in the PLS-SEM to assess discriminant validity (Hair et al. 2019) (Table II). Each latent variable's value must be greater than the highest $R^{2}$ value with the value of the other latent variable. It was found that the constructs do not have any discriminant validity problems according to the Fornell-larger criterion.

Table 2. Fornell-larcker criterion result

\begin{tabular}{lllllll}
\hline Variable & $(1)$ & $(2)$ & (3) & (4) & (5) & (6) \\
\hline Brand Ambassador (1) & 0.863 & & & & & \\
Brand Image (2) & 0.375 & 0.856 & & & & \\
Customer Satisfaction (3) & 0.514 & 0.451 & 0.899 & & & \\
Impulsive Behavior (4) & 0.576 & 0.461 & 0.617 & 0.923 & & \\
Repurchase Intention (5) & 0.610 & 0.497 & 0.727 & 0.673 & 0.903 & \\
Service Quality (6) & 0.520 & 0.291 & 0.582 & 0.519 & 0.599 & 0.853 \\
\hline
\end{tabular}


Structural Model and hypotheses testing results

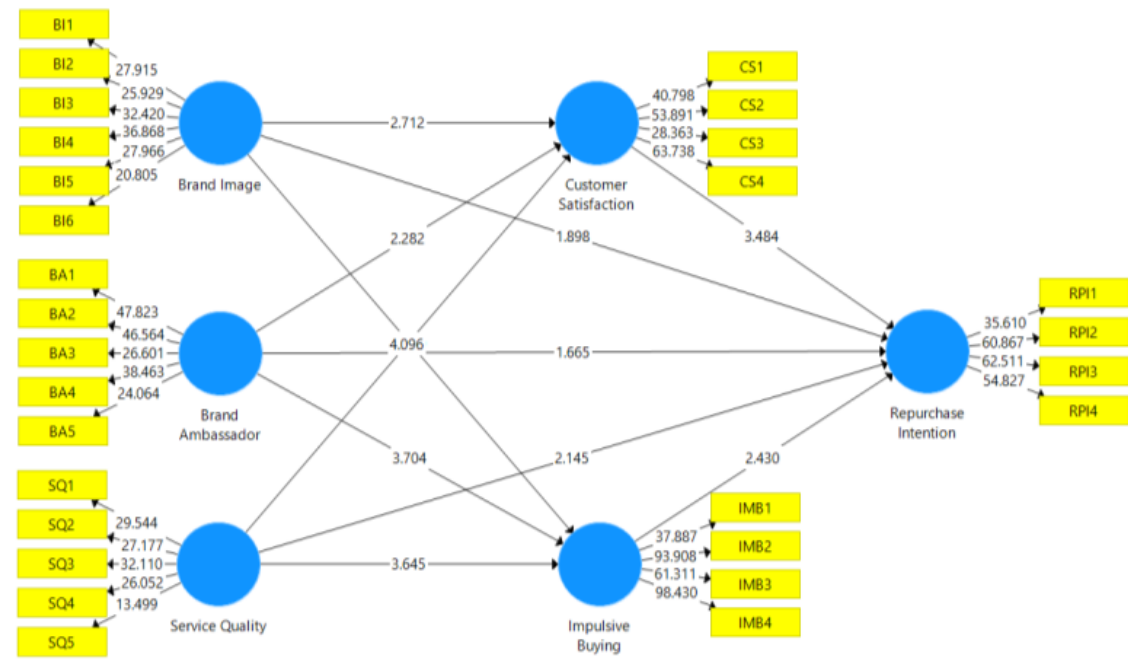

Figure 2: Structural model result

The PLS-SEM structural model, the estimation of the structural model's path coefficient results in Table 3, and Figure 2 shows both the perceived risk $(\mathrm{H} 1: \beta=-0.214 ; \mathrm{t}=2.184 ; \mathrm{p}=0.029$ had a significant effect on perceived usefulness. Also, the perceived risk $(\mathrm{H} 2: \beta=-0.252 ; \mathrm{t}=2.596 ; \mathrm{p}=0.010)$ had a significant effect on perceived ease of use, whereas $(\mathrm{H} 3: \beta=-0.068 ; \mathrm{t}=0.786 ; \mathrm{p}=0.432)$ had a significant effect on trust. Perceived ease of use $(\mathrm{H} 4: \beta=0.529 ; \mathrm{t}=6.385 ; \mathrm{p}=0.000)$ also positively influenced Trust. Perceived usefulness (H5) and perceived ease of use (H6) had a significant effect on attitudes toward use ( $\mathrm{p}=0.016$; $\mathrm{p}=0.021)$, and perceived usefulness significantly influenced intention to use $(\mathrm{H} 7, \mathrm{p}=0.001)$. Additionally, the influence of Trust (H8) attitude toward use was also positive and significant $(\mathrm{p}=0.000)$, whereas attitude toward use also had a positive influence on intention to use (H9: $\beta=0.506 ; p=0.000)$. Overall, only one path was insignificant and did not support the hypothesis (H3), whereas most path coefficient results are statistically significant, and the proposed hypotheses are supported.

Table 3. Path coefficient result with hypotheses testing

\begin{tabular}{|c|c|c|c|c|}
\hline Hypothesis & Path Relationship & T-statistics & P-values & Remarks \\
\hline H1 & Brand Image $\rightarrow$ Customer Satisfaction & 2.712 & 0.007 & Significant \\
\hline $\mathrm{H} 2$ & $\begin{array}{l}\text { Brand Image } \rightarrow \text { Customer Satisfaction } \rightarrow \text { Repurchase } \\
\text { Intention }\end{array}$ & 1.788 & 0.074 & Insignificant \\
\hline $\mathrm{H} 3$ & Brand Image $\rightarrow$ Impulsive Behavior & 3.330 & 0.001 & Significant \\
\hline H4 & Brand Image $\rightarrow$ Impulsive Behavior $\rightarrow$ Repurchase Intention & 1.991 & 0.047 & Significant \\
\hline H5 & Brand Image $\rightarrow$ Repurchase Intention & 1.898 & 0.058 & Insignificant \\
\hline H6 & Brand Ambassador $\rightarrow$ Customer Satisfaction & 2.282 & 0.023 & Significant \\
\hline $\mathrm{H} 7$ & $\begin{array}{l}\text { Brand Ambassador } \rightarrow \text { Customer Satisfaction } \rightarrow \text { Repurchase } \\
\text { Intention }\end{array}$ & 2.266 & 0.024 & Significant \\
\hline H8 & Brand Ambassador $\rightarrow$ Impulsive Behavior & 3.704 & 0.000 & Significant \\
\hline H9 & $\begin{array}{l}\text { Brand Ambassador } \rightarrow \text { Impulsive Behavior } \rightarrow \text { Repurchase } \\
\text { Intention }\end{array}$ & 2.200 & 0.028 & Significant \\
\hline $\mathrm{H} 10$ & Brand Ambassador $\rightarrow$ Repurchase Intention & 1.665 & 0.0907 & Insignificant \\
\hline H11 & Service Quality $\rightarrow$ Customer Satisfaction & 4.096 & 0.000 & Significant \\
\hline H12 & $\begin{array}{l}\text { Service Quality } \rightarrow \text { Customer Satisfaction } \rightarrow \text { Repurchase } \\
\text { Intention }\end{array}$ & 2.721 & 0.007 & Significant \\
\hline H13 & Service Quality $\rightarrow$ Impulsive Behavior & 3.645 & 0.000 & Significant \\
\hline H14 & $\begin{array}{l}\text { Service Quality } \rightarrow \text { Impulsive Behavior } \rightarrow \text { Repurchase } \\
\text { Intention }\end{array}$ & 1.822 & 0.069 & Insignificant \\
\hline H15 & Service Quality $\rightarrow$ Repurchase Intention & 2.145 & 0.032 & Significant \\
\hline H16 & Customer Satisfaction $\rightarrow$ Repurchase Intention & 3.484 & 0.001 & Significant \\
\hline H17 & Impulsive Behavior $\rightarrow$ Repurchase Intention & 2.430 & 0.015 & Significant \\
\hline
\end{tabular}

The study results found that Brand Image is significantly influenced Customer Satisfaction also influence 
impulsive behaviour. This result supported $\mathrm{H} 1$ and $\mathrm{H} 3$. However, it was found that Brand Image insignificantly influences Re-purchase Intention through Customer Satisfaction (H2 and H5 were rejected). These findings were not in line with the previous studies of Tanady and Fuad (2020), Dwi and Ekawati (2019), and Syahrivar et al. (2020), as Brand Image encourage consumers to make the intention to repurchase a product. Whereas, Impulsive Behavior is proved to significantly mediate the Brand Image and Repurchase Intention (H4 is supported). These findings were not in line with Zikra (2020) research that brand image will lead to impulsive behaviour without having the intention or intention to buy beforehand. Brand Ambassador was found to have a significant influence on Customer Satisfaction (H6 is accepted) and Impulsive Behavior (H8 was also accepted). In addition, the mediation effect of Customer Satisfaction and Impulsive Behavior on Brand Ambassador and Repurchase Behavior also proved to have a significant influence (H7 and $\mathrm{H} 9$ were accepted). However, the Brand ambassador was insignificantly influenced on Repurchase Intention (H10 was rejected). It was proved that Brand ambassadors have a stronger connection to a brand and can build customer satisfaction and create an interest to buy. This result has a similar result with a study by Febrina and Sampurno (2017), Fitriana (2020), and Rinaldi and Tanapli (2020). In addition, it was not created an intention to re-purchase in the future. Thus the brand ambassador was more related to the hedonic needs at a time.

For Service quality, in measuring the quality of a product, it was found that most of the hypotheses on Service Quality were accepted (H11, H12, H13, and H15 were accepted) while H14 was rejected. It was found that Impulsive Behavior was insignificantly influenced as mediation of Service Quality and Repurchase Intention. Re-purchase Intention will occur if the consumer feels satisfied and follows the quality of the product or service (Tanady and Fuad, 2020). This result is also supported by Ningsih (2018) and Hidayat (2016) which mentioned that better services provided and good service quality of non-physical facilities create impulsive behaviour.

The result of Customer Satisfaction and Impulsive Behavior were found to accept the hypotheses (H16 and H17 were accepted). This study strengthens the previous research of Kusumadewi and Saraswati (2020) that Customer Satisfaction is an essential basis of the Re-purchase Intention of certain products on a platform as a positive impression with previous experiences (Dewi and Ekawati, 2019). For Impulsive behaviour, once customers feel satisfied during impulsive buying on an earlier transaction, it will create a post-purchase behaviour on re-purchase intention and build a sense of more confidence to use the similar platform in the future (Maulana, 2020).

\section{Conclusion and Recommendation}

Based on the findings, it was interesting that Brand Image and Brand Ambassador insignificantly influenced the Re-purchase Intention, while it influences Impulsive Behavior. Therefore, Tokopedia should also emphasize the quality of the product if the intent is to gain a loyal customer who pursuit re-purchases behaviour in the future. It also found that spending on the Brand Image and Brand Ambassador were only resulted in one-time purchases without strengthening the quality of the product offered. This study also found that impulsive behaviour was found a significant influence on re-purchase behaviour. Although during the first buying, customers did impulsively, they found that it satisfied them. Later, customers will take positive action on post-purchase behaviour by re-purchasing in the future.

This study provides a recommendation that Tokopedia should integrate all the strategies to gain the repurchase intention of the customers. Enhancing the promotional strategy using Brand Image and Brand Ambassador also at the same time should also inform the sellers in the platform to improve the quality of products sold in Tokopedia. By doing this, all efforts can be achieved. The situation of Pandemic, as people are more willing to buy goods online, it creates opportunities to sell more on E-commerce. Thus, Tokopedia should gain more customers to do impulsive buying and become loyal customers as they keep buying the Tokopedia platform. Looking for more products that are on-trend make a hedonic behaviour able to create an impulsive behaviour and ended by purchasing more products on the Tokopedia platform.

\section{References}

Aaker, D. A. (2010). Manajemen Ekuitas Merek alih Bahasa: Aris Ananda. Edisi Revisi. Jakarta: Mitra Utama.

Bagus, E. (2020, October 23). Masyarakat Bisa Vote Artis Tokopedia WIB TV Show. Retrieved from AKURAT.CO: https://akurat.co/iptek/id-1227190-read-masyarakat-bisa-vote-artis-tokopedia-wibtv-show

Bitner, M. J., \& Zeithaml, V. A. (2003). Service Marketing (3rd ed.). New Delhi: Tata McGraw. 
Devita, V. D., Fenalosa, A., \& Hilao, E. (2020, September 2). Pengguna Aktif Bulanan Aplikasi Ecommerce di Indonesia dan Asia Tenggara. Retrieved from iPrice: https://iprice.co.id/trend/insights/pengguna-aktif-bulanan-aplikasi-e-commerce-di-indonesia-danasia-tenggara/

Dewi, R. P., \& Ekawati, N. W. (2019). Peran Kepuasan Konsumen Memediasi Pengaruh Brand Image Terhadap Repurchase Intention. E-Jurnal Manajemen, Vol. 8, No. 5, 2722-2752.

Febrina, M. (2017). Pengaruh Brand Ambassador Dan Hallyu Terhadap Keputusan Konsumen Melakukan Brand Switching dan Implikasinya terhadap Kepuasan Konsumen Kosmetik Di Jakarta. Jurnal Ekonomi, 300.

Ferdinand, A. T. (2002). Metode Penelitian Manajemen : Pedoman penelitian untuk Skripsi, Tesis, dan Desertasi Ilmu Manajemen. Semarang: Badan Penerbit Universitas Diponegoro.

Fildayanti, W. (2020). Pengaruh Online Shopping Convenience Terhadap Repurchase Intention dan EWOM Yang Dimediasi oleh Variabel Customer Satisfaction pada Pengguna E-Commerce. Skipsi, $1-66$.

Fitriana, R. (2020). Analisis Pengaruh Kreativitas Iklan, Kredibilitas Brand Ambassador Dan E-Wom Terhadap Brand Loyalty Grab di Kota Semarang Yang di Mediasi Oleh Kepuasan. Thesis (Masters).

Gideon, A. (2018, December 11). Siapa E-Commerce yang Punya Pengguna Aktif Terbanyak di ASEAN? Retrieved from LIPUTAN6: https:/www.liputan6.com/bisnis/read/4132026/siapa-e-commerceyang-punya-pengguna-aktif-terbanyak-di-asean

Gita, D., \& Setyorini, R. (2016). Pengaruh Brand Ambassador Terhadap Brand Image Perusahaan online zalora. co. id.

Ghozali, I. and Latan, H., 2015. Partial Least Squares: Konsep, Teknik dan Aplikasi Menggunakan Program SmartPLS 3.0 Untuk Penelitian Empiris. 2nd Editio. Semarang: Universitas Diponegoro

Hair, J. F., Christian M. R., Siegfried P. G., Andreas F., Christian N., and Con M. (2019) "Partial least squares structural equation modeling-based discrete choice modeling: an illustration in modeling retailer choice." Business Research 12 (1): 115-142.

Haryantana, I. H., \& Ekawati, N. W. (2015). Pengaruh Celebrity Endorser, Brand Image Dan Persepsi Kualitas Terhadap Niat Beli Sepeda Motor Honda Scoopy di Kota Denpasar. E-Jurnal Manajemen Unud, Vol. 4, No. 9, 2806-2830.

Hidayat, E. W. (2016). Pengaruh Store Atmosphere, Promosi Penjualan, Kualitas Produk Dan Kualitas Pelayanan Terhadap Impulse Buying (Studi Khusus Pada Konsumen ACE Hardware Pondok Indah Mall). Skripsi.

Hootsuite. (2020, January 30). DATAREPORTAL. Retrieved from DIGITAL 2020: GLOBAL DIGITAL OVERVIEW: $\quad$ https://datareportal.com/reports/digital-2020-global-digitaloverview?utm_source=Reports\&utm_medium=PDF\&utm_campaign=Digital_2020\&utm_content =Dual_Report_Promo_Slide

Komalig, A. (2013). Manajemen Hubungan Pelanggan dan Promosi Pengaruhnya Terhadap Kepuasan Debitor Pada PT. Bank Sulut Cabang Calaca Manado. Jurnal EMBA: Jurnal Riset Ekonomi, Manajemen, Bisnis Dan Akuntansi, 1(4), 1145-1153. https://doi.org/10.35794/emba.v1i4.2873

Kotler, Philip, \& Keller, K. (2009). Manajemen Pemasaran Jilid 1. Edisi ke 13. Diterjemahkan oleh Bob Sabran. Jakarta: Erlangga.

Kusumadewi, N., \& Saraswati, T. G. (2020). The Effect of Customer Satisfaction on Re-purchase Interests at Official Store at Shopee and Tokopedia. e-Proceeding of Management: Vol.7, No.2, 6476-6489.

Laroche, M., Kim, C., \& Zhou, L. (2010). Brand familiarity and confidence as determinants of purchase intention: An empirical test in a multiple brand context. Journal of Business Research Vol. 37(2), $115-120$.

Lea-Greenwood, G. (2012). Fashion Marketing Communications E-Book. New Jersey, USA: Wiley Somerset. 93 Ling, K. C., Chai, L. T., \& Piew, T. H. (2010). The Effects of Shopping Orientations, Online Trust and Prior Online Purchase Experience toward Customers' Online Purchase Intention. International Business Research Vol. 3, No. 3; July 2010, 63-76.

Loudon, D. L., \& Bitta, A. J. (2004). Consumer Behavior Concept and Application. Third Edition Singapore: McGraw Hil.

Maulana, B. S. (2020). Pengaruh Kualitas Produk Dan Harga Terhadap Pembelian Impulsive Serta Dampaknya Pada Minat Beli Ulang. Skripsi.

Ningsih, D. (2018). Pengaruh Marketing Mix, Kualitas Pelayanan, Dan Citra Merek Terhadap Impulse Buying Secara Online Mahasiswa Fakultas Ekonomi Dan Bisnis Islam Institut Agama Islam Negeri (Iain) Tulungagung. Skripsi. 
Nugraha, R., Kusumawardani, K. A., \& Octavianie, V. (2018). The Influence of Celebrity Endorsement In Instagram Towards Customer Behavior And Purchase Intention In Healthy Food Diet Business. FIRM Journal of Management Studies Vol. 3 No. 2, 1-24. 94

Parsad, C., Prashar, S., \& Sahay, V. (2017). Impact of Impulsive Personality Traits and Store Environment on Impulse Buying Behavior. Journal of Business and Management, 23 (1/2), 1-24.

Rinaldi, \& Tanpli, Y. E. (2020). Pengaruh Pada Iklan Celebrity Endorser BTSTerhadap Impulsive Buying Behavior Pada Remaja di Kota Padang. Jurnal Pendidikan Tambusai Vol. 4 No. 3, 3457-3463.

Rondonuwu, P. (2013). Kualitas Produk, Harga dan Kualitas Layanan Pengaruhnya Terhadap Kepuasan Konsumen Pengguna Mobil Nissan March Pada PT. Wahana Wirawan Manado. Jurnal Riset Ekonomi, Manajemen, Bisnis Dan Akuntansi, 1(4), 718-728. https://doi.org/10.35794/emba.v1i4.2755

Royan, F. (2004). Marketing Celebrities. Jakarta: PT. Elex Media Komputindo.

Salisbury, W. D., Pearson, R. A., Pearson, A. W., \& Miller, D. W. (2001). Perceived security and World Wide Web purchase intention. Industrial Management \& Data Systems, 165-177.

Santoso, R. (2020). Review of Digital Marketing \& Business Sustainability of E-Commerce During. Jurnal Ilmu Ekonomi Terapan, Vol. 5, No.2, Desember 2020, 40.

Septila, R., \& Aprilia, E. D. (2017). Impulse buying pada mahasiswa di Banda Aceh. Psikoislamedia: Jurnal Psikologi, 56-63.

Setiawan, D. V. (2018). The Impact of Brand Image, Service Quality, And Sales Promotion on Customer Re-purchase Intention Through Customer Satisfaction at Tokopedia In Surabaya. Thesis.

Setyobudi, D., \& Bintoro, I. (2014). Konsumen dan Pelayanan Prima. Yogyakarta: Gava Media.

Setyowati, D. (2020, November 9). Pengguna Internet Indonesia Naik Jadi 196,7 Juta, Peluang Bagi Startup. $\quad$ Retrieved from katadata: https://katadata.co.id/desysetyowati/digital/5fa911794f3e6/pengguna-internet-indonesia-naik-jadi196-7-juta-peluang-bagi-startup

Solomon, M. R., \& Rabolt, N. (2009). Consumer Behavior in Fashion. USA: Pearson/Prentice Hall.

STATISTA. (2020, June 11). Statista Global No.1 Business Data Platform. Retrieved from Statista ECommerce Data Market Outlook: https://www.statista.com/outlook/243/120/ecommerce/indonesia\#market-revenue

Tanady, E. S., \& Fuad, M. (2020). Analisis Pengaruh Citra Merek dan Kualitas Layanan Terhadap Keputusan Pembelian Tokopedia di Jakarta. Manajemen Pemasaran Jurnal Vol. 9 No. 2, 113-123.

Tjiptono, F. \&. (2016). Service Quality and Satisfaction. Yogyakarta: Andi.

Wicaksono. (2007). Perilaku Konsumen. Jakarta: PT. Index Jakarta.

Yulianto, A. D. (2017). Pengaruh Harga, Kualitas Produk dan Kualitas Layanan Terhadap Kepuasan Pelanggan Kentucky Fried Chicken (KFC) Surabaya. Thesis.

Zakaria, G., \& Suwitho, S. (2019). Pengaruh Kualitas Pelayanan, Kualitas Produk Dan Harga Terhadap Kepuasan Pelanggan. Vol 6 No 4 (2017): Jurnal Ilmu dan Riset Manajemen, 2.

Zikra, R. (2020). Pengaruh Citra Merek Dan Locus of Control Terhadap Pembelian Impulsif Pada Konsumen Yang Berbelanja Di Toko Daring. Thesis.

Gita, D. (2016). Pengaruh Brand Ambassador Terhadap Brand Image Perusahaan Online Zalora.Co.Id. In National.

Wang, F., \& Hariandja, E. (2016). The Influence of Brand Ambassador On Brand Image And Consumer Purchasing Decision: A Case Of Tous Les Jours. International Conference on Entrepreneurship. 